\title{
数值制御工作機械の送り駆動系における 消費電力の測定と評価
}

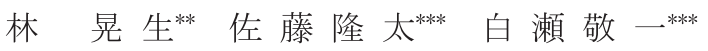

\begin{abstract}
Measurement and Evaluation of Electric Power Consumption of Feed Drive Systems in NC Machine Tool
\end{abstract}
Akio HAYASHI, Ryuta SATO and Keiichi SHIRASE

\begin{abstract}
Reducing the electric power consumption in NC machine tools is strongly demanded in these years, because the NC machine tools are one of the main facilities in the manufacturing field. Thus measuring tests of the power consumption in an NC machine tool for all components were measured in other studies up to now. This study focused onto the power consumption of feed drive systems. In this study, electric power consumption of an actual 5-axis vertical type machining center consists of X, Y, $\mathrm{Z}, \mathrm{B}$ and $\mathrm{C}$ axes is measured. In order to investigate the electric power consumption of feed drive systems, currency and voltage of servo amplifiers are measured. At first, the measuring tests of each axis are carried out under various feed rate. As the results of the measurements, it is clarified that the power consumption depends on the motion velocity and torque. In addition, acceleration-deceleration parameters and servo gains are also changed to investigate the influences of the parameters. These parameters have big influences on the power consumption during the acceleration-deceleration process. The results of this study show that the electric power consumption might be reduced by changing the motion and parameters of the axes.
\end{abstract}

Key words : NC machine tool, feed drive system, electric power consumption, acceleration-deceleration, servo gain, gravity

\section{1. 諸言}

近年，地球温暖化やエネルギ資源の枯渇といった問題から， 省エネ化は世界のあらゆる場で推進されている. 日本国内では, 原子力発電所の停止, 全国的な電気料金の值上げなど様々な要 因から節電の意識が高まっている，そのため，生産現場におい ては, 改正省エネ法が施行される等, 工場で消費される電力に 目が向けられている。これまで, 工場におけるエネルギ問題に ついては，工場全体の電力を測定し管理する方法や，生産プロ セスにおけるエネルギを算出する方法が提案されてきた ${ }^{123) . ~}$

工場での節電の取り組みを行うためにも, 生産設備そのもの の消費電力削減が望まれている，工場でのエネルギ使用量の割 合は生産設備が 8 割以上を占めており，そのため，特に生産設 備の中核を占める工作機械の消費電力削減は重要であるといえ る.このことから, 工作機械の消費電力を明らかにするため様々 な研究がおこなわれてきたが，それらは主に工作機械全体の消 費電力を検討するものだった ${ }^{4)-6)}$. その結果, クーラントやイ ンバータなどの周辺設備の消費電力が大きいことが明らかにさ れ，その消費電力削減がなされてきた.

しかし，実際に工作機械の消費電力を測定してみると，工作 機械の運動創成に関わる送り駆動系の消費電力も無視できない これまで, 工作機械の送り駆動系については, 位置決め精度や 摩擦特性について多くの研究 7)12)がなされてきたが, その消費 電力に関する研究は少ない. しかし，送り駆動系の消費電力は 運動方向や送り速度, 制御パラメータといった様々な要素の影 響によって大きく変化することが考えられる.

そこで本研究では, 工作機械の送り駆動系の消費電力に着目 し，その消費電力の影響を及ぼす因子を明らかにすることで, 消費電力を削減する方法を検討することを目的とする，送り駆

* 原稿受付 平成 25 年 5 月 23 日

** 学生会員 神戸大学大学院工学研究科 (神戸市灘区六甲台町 1-1)

*** 正 会員 神戸大学大学院工学研究科
動系はターニングセンタやマシニングセンタ, 複合加工機など の数值制御工作機械だけでなく, 搬送装置やロボットなどの一 般産業機械など生産設備において幅広く使用されている為, 送 り駆動系の消費電力削減はこのような生産設備全般での消費電 力削減につながることが期待される.

\section{2. 測 定 方 法}

本研究では図 1 に示寸ような立て形 5 軸制御マシニングセン 夕を対象に消費電力の測定を行った. また, 図 2 に送り駆動機 構を模式的に示す. 図に示すように, 直進軸は全て主軸側に配 置され, $\mathrm{Y}$ 軸の上で $\mathrm{X}$ 軸, $\mathrm{X}$ 軸の上で $\mathrm{Z}$ 軸が駆動する構造とな っている. テーブル側には回転軸が配置され， B 軸の上で $\mathrm{C}$ 軸

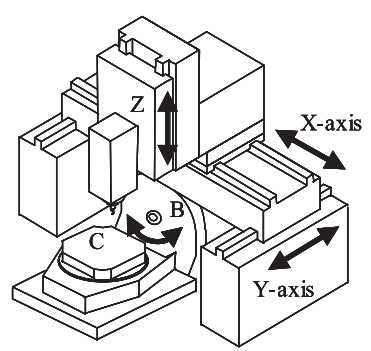

Fig.1 5-axis machining center

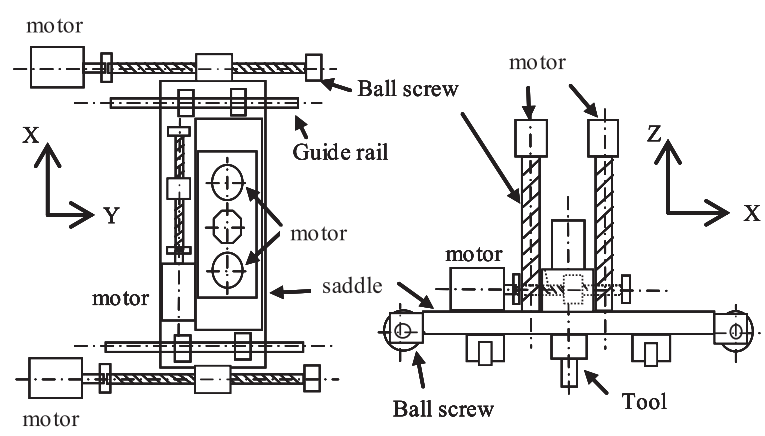

Fig.2 Structure of feed drive systems 
Table 1 Rated motor torque and output of each axis

\begin{tabular}{c|c|c}
\hline Axis & Rated motor torque Nm & Rated motor output $\mathrm{kW}$ \\
\hline $\mathrm{X}$ and $\mathrm{Y}$ & 9.55 & 3.0 \\
\hline $\mathrm{Z}$ & 5.97 & 2.5 \\
\hline $\mathrm{B}$ & 950 & 7.2 \\
\hline $\mathrm{C}$ & 200 & 3.2 \\
\hline
\end{tabular}

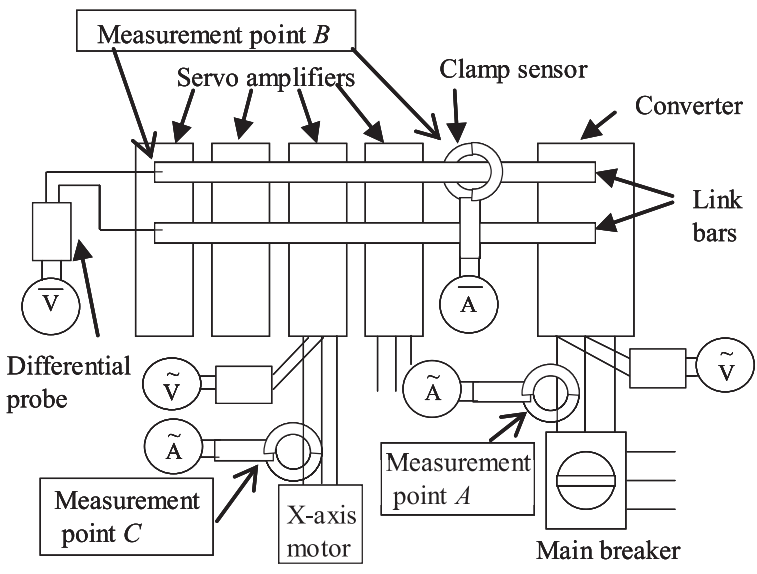

Fig.3 Measurement points

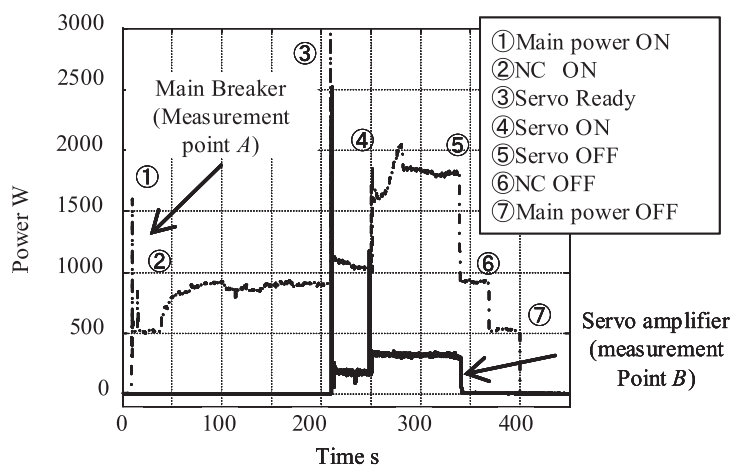

Fig.4 Measurement results of power consumption at main breaker and servo amplifiers

が駆動する構造となっている．直進軸はモータとボールねじに より駆動され，Y 軸および Z 軸は 2 本のボールねじによって駆 動されている．また，回転軸は両軸ともダイレクトドライブモ 一タにより直接駆動されている．各軸に使用されているモータ の定格トルクおよび出力を表 1 に示す.

消費電力の測定箇所を模式的に図 3 に示す．本研究では，送 り駆動系のみの消費電力を測定するため, メインブレーカ部(図 3 中の測定点 A）と，コンバータとサーボアンプをつなぐリン クバー (図 3 中の測定点 B) の 2 箇所で測定を行い結果を比較 した．電流はクランプ型の電流計を用いて電圧に変換し，電圧 は差動プローブを使って 1000 分の 1 に変換して測定したものを, データロガーによって記録した，電力は測定された電流と電圧 の積として算出した。 メインブレーカ部では三相 $200 \mathrm{~V}$ の交流 電圧となるため, 実効電力を計算する際の力率は一般的な值と される 0.8 とした. 一方, サーボアンプ部では, 電圧はコンバ ータによって直流に整流されるため力率は用いず計算を行った. 送り軸の運動は行わず, 主電源投入から運転準備を完了した 後, 主電源をオフするまでの電力を測定した結果を図 4 に示す. 図 4 によると, メインブレーカ部における測定結果では, 主電 源を投入しただけで約 $500 \mathrm{~W} ， \mathrm{NC}$ の電源を投入することで約

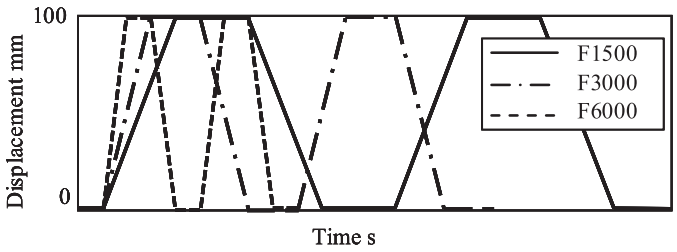

Fig.5 Motion pattern for measurement tests

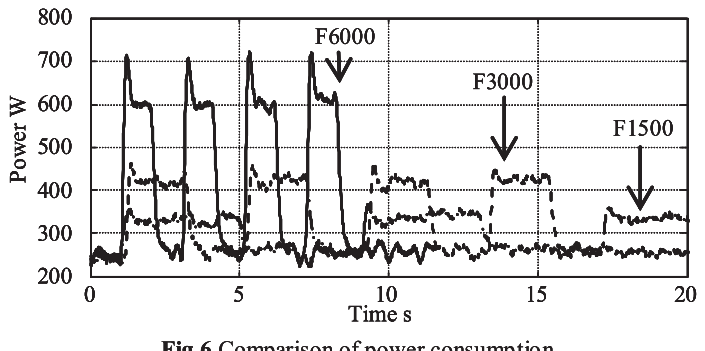

Fig.6 Comparison of power consumption of $\mathrm{X}$-axis with each velocity

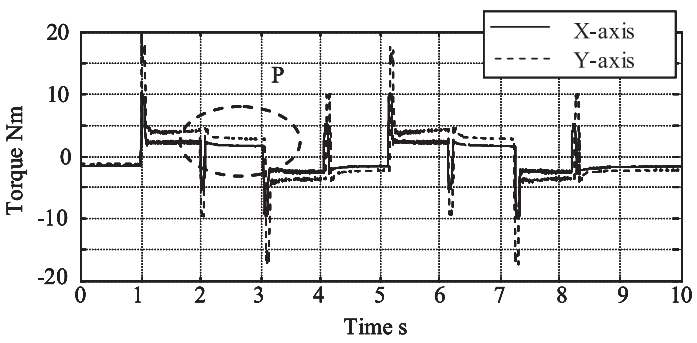

(a) Motor torque

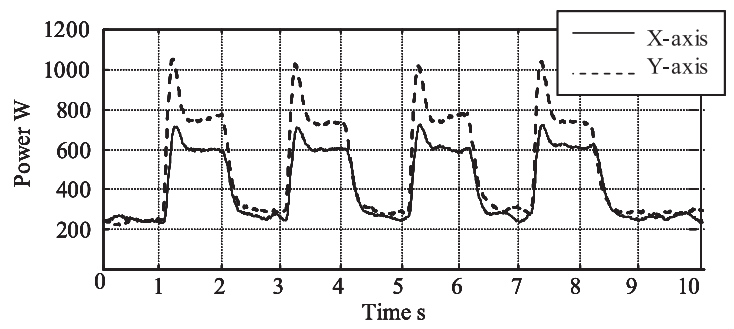

(b) Power consumption

Fig.7 Power consumption of $\mathrm{X}$-and $\mathrm{Y}$-axis

$1 \mathrm{~kW}$ の電力が消費されており, これらには送り駆動系での消費 電力に加えて $\mathrm{NC}$ 本体や周辺機器の消費電力が含まれている.

一方, サーボアンプ部における測定結果では, サーボオン状態 以外での消費電力はゼロとなっており, サーボオン時に電力が 立ち上がっている．このことから，サーボアンブ部で電力を測 定することで周辺機器による影響を含まない送り駆動系のみの 消費電力が測定できると考えられる.

よって本研究では, 送り駆動系のみの消費電力を議論するた めサーボアンプ部で消費電力の測定を行うこととする.

\section{3. 送り駆動系の消費電力}

\section{1 直進軸の消費電力}

直進軸（X 軸, $\mathrm{Y}$ 軸,および Z 軸）が送り運動中に消費する電 力を測定するために, $1500,3000,6000 \mathrm{~mm} / \mathrm{min}$ の 3 通りの送 り速度で, 初期位置から $100 \mathrm{~mm}$ の距離を 2 往復させたときの 消費電力を測定した. 動作パターンの模式図を図 5 に示す。 0 $\mathrm{mm}$ および $100 \mathrm{~mm}$ の位置地点ではドウエル指令により静止さ せ，そのときの静止時間は $100 \mathrm{~mm}$ を移動するのに要する時間 と同じになるように設定した。測定は各軸を別々に動かして行 


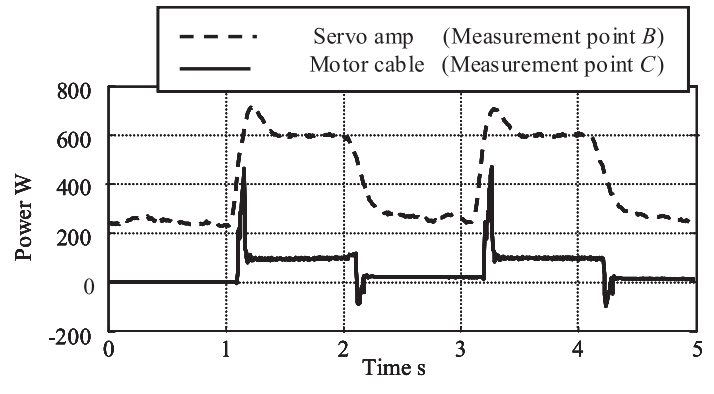

Fig.8 Comparison of measured results at servo amplifiers and motor cable

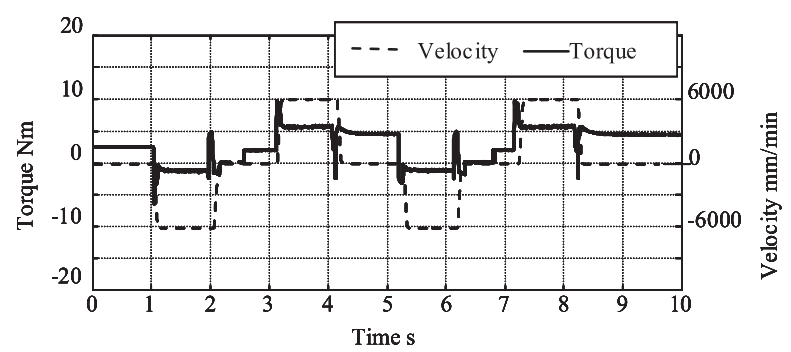

(a) Motor torque and velocity

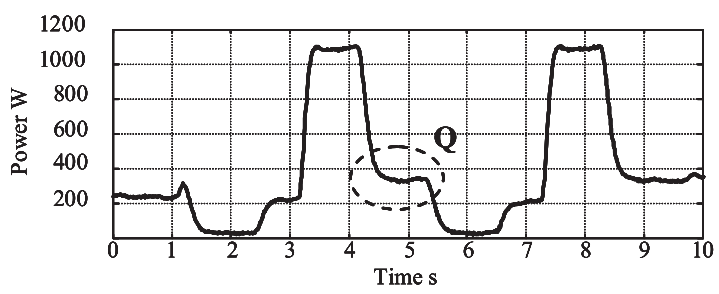

(b) Power consumption

Fig.9 Power consumption of Z-axis

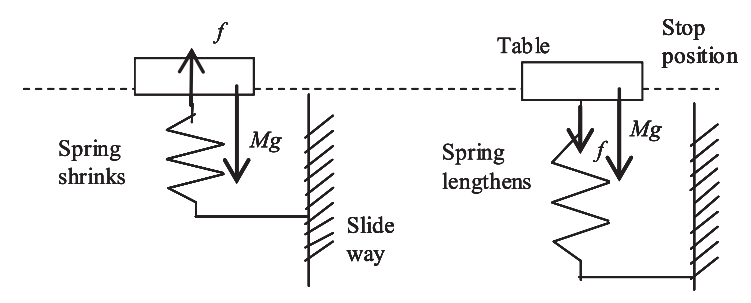

(a) After down direction motion

(b) After up direction motion

Fig.10 Friction force direction of $\mathrm{Z}$-axis

い，そのときの速度および各軸のトルクについても $\mathrm{NC}$ の波形 診断機能を用いて取得した. 図 6 に各速度におけるX軸の消費 電力を示す，図によると，速度に依存して消費電力が大きくな ることがわかる。

送り速度を $6000 \mathrm{~mm} / \mathrm{min}$ として X 軸と Y 軸を動かしたとき の測定結果を図 7 に示寸。ここで, 図 7(a)はモータトルク，(b) は消費電力である. 本研究で測定の対象としたマシニングセン

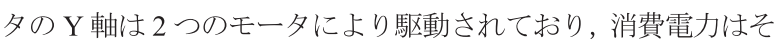
の合計を示している．消費電力についてみると，X軸，Y 軸と もに加速時に大きく電力が消費されていることがわかる.また, $\mathrm{Y}$ 軸を動かしたときの消費電力が $\mathrm{X}$ 軸よりも大きくなっている これは, 測定対象とした機械では Y 軸の上で X 軸が駆動する構 造になっており，Y 軸のほうが被駆動体の質量が大きいためで ある、図 7(a)をみると，Y軸のモータトルクが X軸よりも大き くなっていることがわかる.

送り運動後に静止しているときのモータトルク（図 6(b)中の

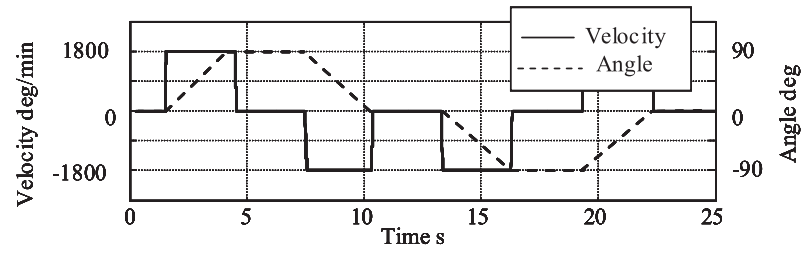

(a) Velocity and angle

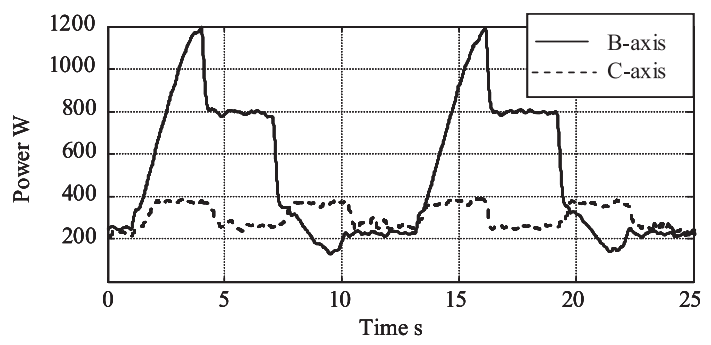

(b) Power consumption

Fig.11 Power consumption of B- and C-axis

P 部）は運動中とほぼ同じであるが，停止中の電力は運動中と 比べて大きく下がる. ここで, 停止中に発生するトルクについ ては, ボールねじ送り駆動系におけるころがり案内の摩擦力を 微視的にみると非線形ば称特性を有していることが知られてお

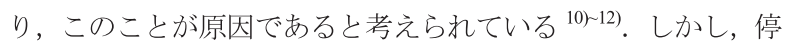
止中には速度がゼロとなり, 運動に要するエネルギがないため 電力が大きく下がると考えられる. 以上のことから, 運動中の 消費電力は速度とトルクの両方に依存しているといえる.

また両軸とも，停止中に $250 \mathrm{~W}$ の電力を消費している.この 原因を明らかとするために，X軸のモータ動力ケーブル部(図 3 中の測定点 C) で消費電力の測定を行い, サーボアンプ部での 測定結果と比較した. X軸を送り速度 $6000 \mathrm{~mm} / \mathrm{min}$ で動かした 時の測定結果を図 8 に示す. 図より, モータ動力ケーブル部の 測定結果では, 停止中の消費電力がゼロになっていることがわ かる. このことから, サーボアンプ部での測定結果においてみ られる停止中に消費される電力は, サーボアンプが定常的に消 費している電力であると考えられる.

送り速度 $6000 \mathrm{~mm} / \mathrm{min}$ でZ軸を $100 \mathrm{~mm}$ 運動させたときの速 度とモータトルクを図 9(a), 消費電力の測定結果を図 9(b)に示 寸. なお， Z 軸も $\mathrm{Y}$ 軸同様に2つのモータで駆動されているた め, 消費電力はその合計を示している．図 9(b)をみると， Z 軸 の消費電力は上昇時に極端に大きく, 下降時にはゼロに近い. これは重力による影響である。 また，Z軸は停止中の消費電力 にも違いが見られ, 図 9(b)中の $\mathrm{Q}$ 部に示寸ように, 上昇後に停 止した場合のほうが下降後に停止した場合よりも電力が大きく なっている.ささら図9(a)をみると, 停止中のトルクに関して も上昇後に停止した場合のほうが下降後に停止した場合よりも 大きくなっている.すべり案内面の摩擦力をバネ要素で表した 研究例 ${ }^{8}$ をもとにこの現象を模式的にあらわしたものを図 $10 に$ 示す．図によると，Z軸が下降運動を行った後では，摩擦力は ばねが縮んだ状態であらわされ，重力と逆方向に作用するため $\mathrm{Z}$ 軸にかかる力は小さくなる. 一方, 上昇運動後には, 摩擦力 はばねが伸びた状態であらわされ重力と同じ方向に作用するた め, Z 軸にかかる力が大きくなると考えられる.このことから， $Z$ 軸停止中のモータトルクが摩擦特性に起因して直前の運動方 向に依存することで, 停止中の消費電力も直前の運動方向によ り変化するといえる. 


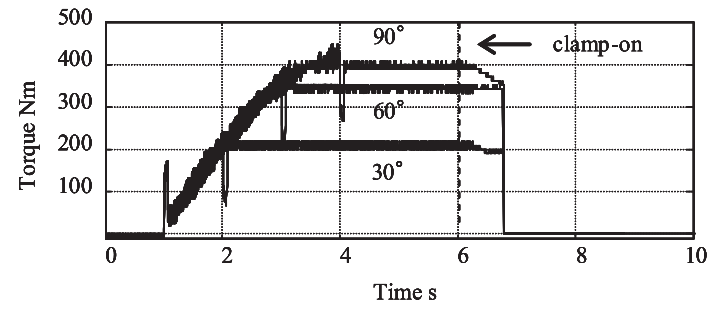

(a) Motor torque

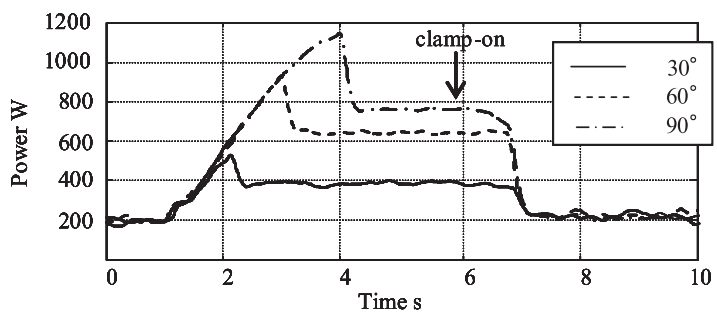

(b) Power consumption

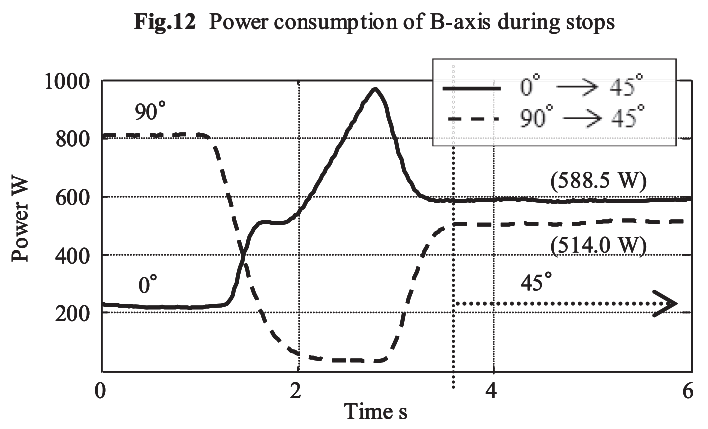

Fig.13 Influence of the motion direction to the power consumption of $\mathrm{B}$-axis during stops

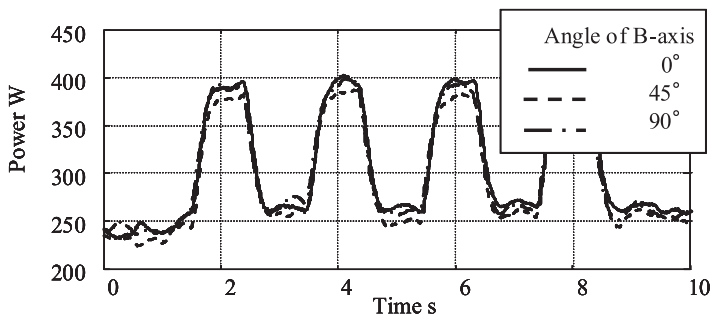

Fig.14 Influence of the angle of B-axis to the power consumption of $\mathrm{C}$-axis

\section{2 回転軸の消費電力}

回転軸（B 軸と C 軸）動作中の消費電力を明らかにするた め, 900, 1800 および $3600 \mathrm{deg} / \mathrm{min}$ の 3 通りの送り速度で, 初期位置から $90^{\circ}$ 回転させたときの消費電力を測定した．その

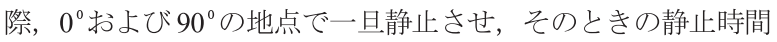
は $90^{\circ}$ 回転するのに要する時間と同じになるように設定した. 送り速度 $1800 \mathrm{deg} / \mathrm{min}$ で動作させた時の速度と角度の変化を 図 11(a)に，消費電力を図 11(b) に示寸．図によると，C 軸と比 べて, 重力の影響を受ける B 軸の消費電力は極端に大きくなっ ているほか，回転方向により消費電力が大きく違う。また B 軸 を $90^{\circ}$ 傾けた状態で停止させたときの消費電力は, $800 \mathrm{~W}$ とか なり大きい. なお, 速度を変化させたときの消費電力は, 両軸 共に速度に依存して増加した。

$\mathrm{B}$ 軸停止中の消費電力について明らかにするため, B 軸を $1800 \mathrm{deg} / \mathrm{min}$ の速度で $30^{\circ}, 45^{\circ}, 60^{\circ}$ および $90^{\circ}$ 回転させ，回 転後に静止させた時のトルクと消費電力とを図 12(a)および(b) にそれぞれ示す。ここで, 運動開始から5秒後に回転軸を機械

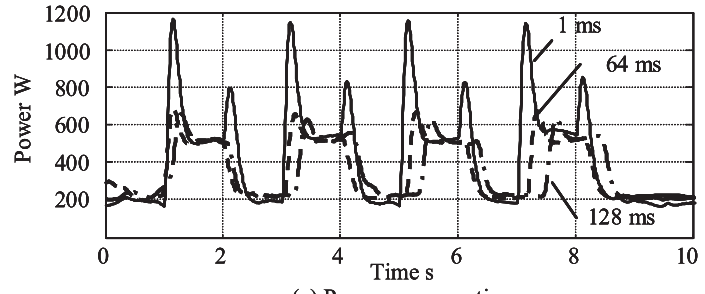

(a) Power consumption

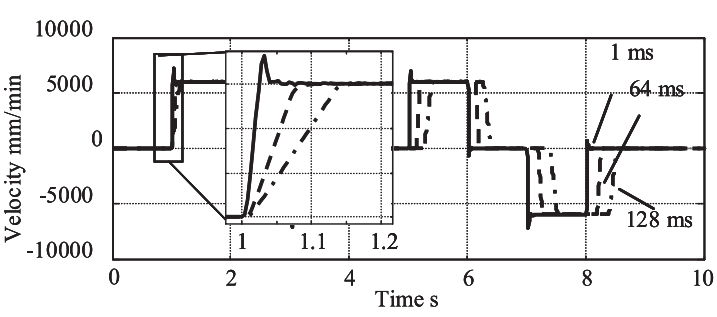

(b) Velocity

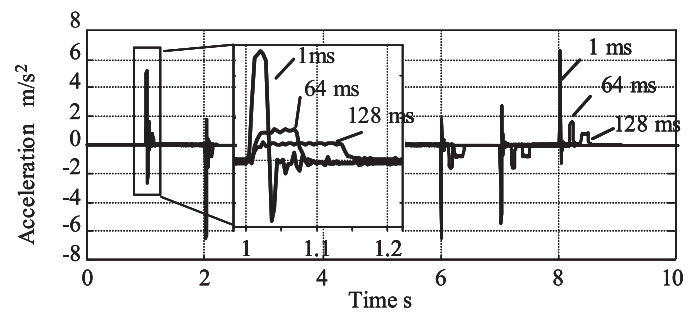

(c) Acceleration

Fig.15 Influence of acceleration-deceleration time

的にクランプする指令を出している. 図 12 によると, 機械的な クランプをした状態ではトルクおよび消費電力は発生しておら ず，クランプを解除すると消費電力およびトルクが発生する. この時の消費電力は角度に依存しており, $90^{\circ}$ 傾けて停止させ た時の消費電力は図 11(b)に示した停止中の消費電力と同じで ある. また, 本実験機における B 軸および $\mathrm{C}$ 軸のクランプ方式 は，油圧式のディスクブレーキであり，クランプのための電力 を消費しない，このことから，B 軸を静止させたときの消費電 力は停止角度に応じたトルクに依存しており, 機械的なクラン プを活用することで $\mathrm{B}$ 軸を静止させたときの消費電力を削減で きることがわかる.

さらに，重力の影響を受ける B 軸停止中の消費電力が， Z 軸 同様に直前の運動方向により変化することが予想されたため, $\mathrm{B}$ 軸を $0{ }^{\circ}$ から $45^{\circ}$ まで回転させ停止した場合と, $90^{\circ}$ から $45^{\circ}$ まで回転させ停止した場合の消費電力を測定し比較した。 その 結果を図 13 に示寸. 図より, B 軸停止中の消費電力が直前の運 動方向により大きく違うことがわかる．このことは Z 軸同様, $\mathrm{B}$ 軸停止中のモータトルクが, 摩擦特性に起因して直前の運動 方向に依存することで，消費電力に影響を及ぼすためであると 考えられる.

一方, $\mathrm{C}$ 軸の消費電力に $\mathrm{B}$ 軸の傾斜角度により重力の影響を 明らかにするため, $\mathrm{B}$ 軸を $45^{\circ}$ および $90^{\circ}$ に傾斜させた状態で $\mathrm{C}$ 軸を回転させたときの消費電力を測定した. 図 14 に測定結果を 示す.この結果, $\mathrm{C}$ 軸の消費電力は $\mathrm{B}$ 軸の傾斜角度に依存しな いことが明らかとなった。このことは，C軸はダイレクトドラ イブモータにより直接駆動されており, モータがその中心に位 置しているため, モーメントに影響を受けずトルクに変化がな いためである. しかしながら，テーブル上にワークを設置した 場合には，ワーク形状や設置場所によっては偏心が生じること で，その消費電力が変化することが予想される. 
Table 2 Comparison of energy consumption influenced by acceleration time

\begin{tabular}{c|c|c}
\hline $\begin{array}{c}\text { Acceleration time } \\
\mathrm{ms}\end{array}$ & $\begin{array}{c}\text { Motion time } \\
\mathrm{s}\end{array}$ & $\begin{array}{c}\text { Energy consumption } \\
\mathrm{J}\end{array}$ \\
\hline 1 & 8.02 & 4081 \\
\hline 64 & 8.26 & 3592 \\
\hline 128 & 8.64 & 3629 \\
\hline
\end{tabular}

\section{4. 制御パラメータの影響}

\section{1 加減速時定数の影響}

制御パラメータによる影響を調査するために，X軸送り駆動 系のサーボゲインや加減速時定数を変え, 送り速度 6000 $\mathrm{mm} / \mathrm{min}$ で $100 \mathrm{~mm}$ の距離を 2 往復させたときの消費電力を測定 した. 加減速時定数を 1,64 , および $128 \mathrm{~ms}$ の 3 通りに変化さ せた時の測定結果を図 15(a)に示す．このとき，加減速時定数に よる影響のみを調べるため, 位置ループゲインは $10 \mathrm{~s}^{-1}$ として ある。また，この時の速度と加速度の変化を図 15(b)および(c) にそれぞれ示寸．眓 15(a)によると，時定数を $1 \mathrm{~ms}$ とした場合 には加減速時の消費電力が極端に大きくなることがわかる．し かし，等速中の消費電力に変化はみられなかった．また，速度 をみると加減速時にオーバシュートが生じていることがわかる， さらに加減速時定数を $1 \mathrm{~ms}$ とした場合には減速時にも電力が 消費されている. 加速度の変化(図 15(c))をみると, 加速時と減 速時の両方で加速度波形に振動がみられ，このことが加減速時 の消費電力が極端に大きくなったことの原因であると考えられ る.

一方，時定数を $128 \mathrm{~ms}$ に設定すると，加減速時の消費電力は 小さくなっている．消費電力のピークを抑えるためには加減速 時間を大きく設定することが有効であると考えられる.しかし， 加速度の変化を見ると，時定数を大きくした場合，加速度は小 さくなるが加速に要する時間が長くなっているため, 運動に要 する時間が増大している，すなわち，加減速時定数が短すぎて も長すぎても, 総消費エネルギが増加するといえる，このこと は，運動に要する総消費エネルギを最小にする加減速時定数が 存在することを示唆している.

加減速時定数の影響による運動に要する消費エネルギの違 いを調査するために, 加減速時定数を変えて $100 \mathrm{~mm}$ の距離を 2 往復したときの消費電力を時間積分した. このときの運動に 要する時間は加減速時定数によって変化するため, 積分時間は 運動開始から 2 往復の運動が終わり 3 往復目を開始するまでの 時間とした，運動に要した時間と消費エネルギの計算結果を表 2 に示す. 表 2 によると, 加減速時定数を $1 \mathrm{~ms}$ と小さく設定し た場合には運動時間が短くなるものの, 総消費エネルギは最も 大きい.これは加減速時の消費エネルギが極端に大きくなって しまっているためである. そのため, 加減速時定数を $64 \mathrm{~ms}$ と すると， $1 \mathrm{~ms}$ の場合に比べて 14 \%消費エネルギが小さくなる ことがわかる。

一方, 加減速時定数を $128 \mathrm{~ms}$ と大きく設定した場合には運動 に要する時間が長くなり, 時定数を $64 \mathrm{~ms}$ とした場合と比べて 総消費エネルギの差は $1 \%$ と，ほとんど違いはみられない．以 上のことから，最適な加減速時定数を設定することで運動に要 する総消費エネルギの削減が可能であることがわかる.

\section{2 サーボゲインの影響}

同様の運動条件で, 位置ループゲインを 10,60 , および $120 \mathrm{~s}^{-1}$
Table 3 Comparison of energy consumption influenced by position loop gain

\begin{tabular}{c|c|c}
\hline $\begin{array}{c}\text { Position loop gain } \\
\mathrm{s}^{-1}\end{array}$ & $\begin{array}{c}\text { Motion time } \\
\mathrm{s}\end{array}$ & $\begin{array}{c}\text { Energy consumption } \\
\mathrm{J}\end{array}$ \\
\hline 10 & 8.00 & 3407 \\
\hline 60 & 8.01 & 3720 \\
\hline 120 & 8.02 & 4081 \\
\hline
\end{tabular}

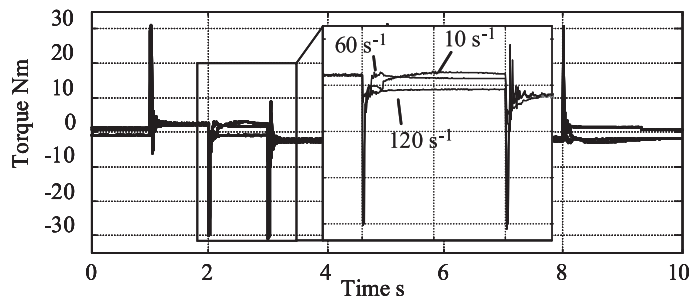

(a) Motor torque

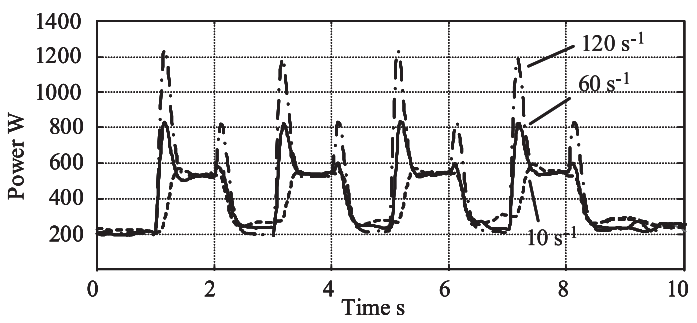

(b) Power consumption

Fig.16 Influence of position loop gain

と変化させた時のトルクの変化を図 16(a)に示す.また, 消費電 力の測定結果を図 16(b)に示す.このとき, 位置ループゲインに よる影響のみを調べるため，加減速時定数は $1 \mathrm{~ms}$ としてある. 図 16(b)によると, 位置ループゲインを $120 \mathrm{~s}^{-1}$ と大きくした場合 には加速時の消費電力が大きくなり, 減速時にも電力が大きく 消費されている，一方，位置ループゲインを $10 \mathrm{~s}^{-1}$ とした場合 には，加減速時の消費電力はほかと比べて大幅に小さくなって いるが，運動に要する時間は大きく変化していない. よって, 運動精度が要求されない場合には, 位置ループゲインを小さく 設定することで運動に要する総消費エネルギを削減できる可能 性がある。

また，どの場合にも等速運動中の消費電力に大きな違いはみ られないが，停止中の消費電力がわずかに大きくなっている. トルクの変化(図 16(a))をみると，位置ループゲインを $10 \mathrm{~s}^{-1}$ と した場合は停止中のトルクがほかの位置ループゲインの場合と 比べて大きく発生しており，このことが停止中に消費電力が増 大していることの原因と考えられる.

位置ループゲインの影響による運動に要する消費エネルギ の違いを調査するため, $100 \mathrm{~mm}$ の距離を二往復させた時の消 費エネルギを算出した。 運動に要した時間と消費エネルギの計 算結果を表 3 に示す. 表 3 によると, 位置ループゲインを変化 させても運動に要する時間は変わらないが, サーボゲインを小 さく設定した場合に総消費エネルギが小さくなることがわかる. 特に, 位置ループゲインを $10 \mathrm{~s}^{-1}$ と設定した場合には, $120 \mathrm{~s}^{-1}$ と設定した場合に比べて約 $16 \%$ も消費エネルギが小さくなっ ている.これは, 位置ループゲインを $10 \mathrm{~s}^{-1}$ と設定した場合, 加減速時の消費電力が極端に小さくなっているためである．以 上のことから, 位置ループゲインを小さく設定することで, 運 動時間に影響を与えることなく，その運動に要する消費エネル ギを削減可能であることがわかる. 


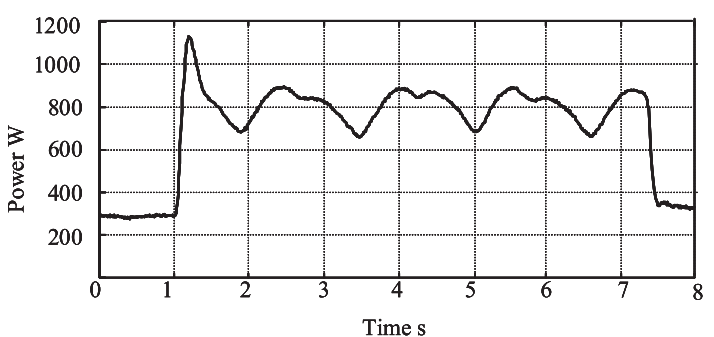

Fig.17 Power consumption under circular motion

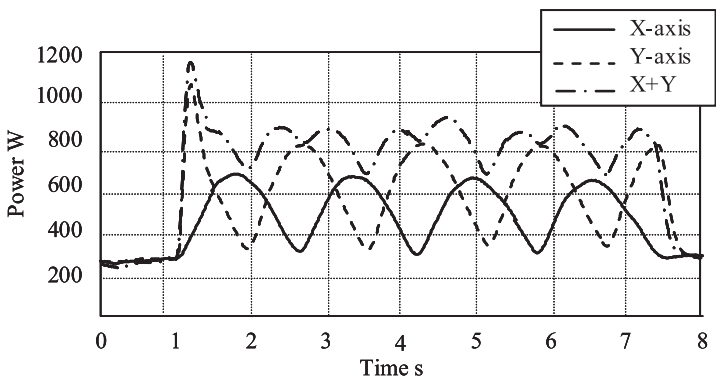

Fig.18 Power consumption of $\mathrm{X}$-and $\mathrm{Y}$-axis under circular motion

\section{5. 同時多軸制御時の消費電力}

\section{1 同時 2 軸制御運動}

同時多軸制御運動時の消費電力について明らかにするため, まず，同時 2 軸制御である円運動時の消費電力を測定した. XY 平面上で半径 $50 \mathrm{~mm}$, 送り速度 $6000 \mathrm{~mm} / \mathrm{min}$ の円運動を 0 度の 位置から 2 周行ない，その時の消費電力を測定した。測定結果 を図 17 に示寸. 図によると, 円運動中の消費電力は周期的に変 動している. 周期的な変動の原因を調べるため, 円運動時と同 じ運動を各軸に指令して 1 軸ごとに運動を行わせ, 円運動時に おけるX軸およびY 軸の消費電力を個別に測定した. その結果 を図 18 に示寸. 図によると, 各軸の消費電力が周期的に変動し ており，これは円運動時に各軸の速度が周期的に変動するため である。 また，2つの軸の消費電力の合計は，同時 2 軸制御時 の消費電力と同じ波形となっている。この結果から, 同時 2 軸 制御時の消費電力はそれぞれの軸において消費される電力の合 計であるといえる。

\section{2 同時 5 軸制御運動}

回転軸も含む同時多軸制御運動として, 円すい台加工運動を 行った時の消費電力を測定した，送り運動にのみ要する電力を 測定するため, 主軸の回転などは行わず送り動作のみを指令し た．図 19 に円すい台の想定形状，図 20 に運動中の各軸の速度 条件を示す. また, 想定する加工条件とワークの設置条件を表 4 に示す. 円すい台加工運動時における消費電力の測定結果を 図 21(a)に示す. また, 円運動の場合と同様に, 円寸い台加工運 動と同じ運動を各軸に指令することで, 各軸単体での運動を行 つて消費電力を測定した，その結果を図 21(b)に示す。さらに, 各軸の消費電力を合計した結果も図 21(a)にあわせて示す. 図 21 によると, 各軸の消費電力の合計が同時多軸制御時の消費電 力と同じ波形になっており, 回転軸を含む同時多軸制御運動時 における消費電力も, 各軸の消費電力の合計であらわすことが できるといえる. また, 図 21(b)の各軸の消費電力をみると, X 軸, $\mathrm{Y}$ 軸および $\mathrm{C}$ 軸は速度の変化が大きいのにもかかわらず消 費電力の変化は小さく, 全体の消費電力にはほとんど影響がな いことがわかる.
Table 4 Cutting and setting conditions

\begin{tabular}{c|c}
\hline Tool type & Square end mill \\
\hline Tool diameter & $10 \mathrm{~mm}$ \\
\hline Feed rate & $600 \mathrm{~mm} / \mathrm{min}$ \\
\hline Inclination angle & $10 \mathrm{deg}$ \\
\hline Half apex angle & $15 \mathrm{deg}$ \\
\hline Center offset & $60 \mathrm{~mm}$ \\
\hline Diameter of bottom surface & $90 \mathrm{~mm}$ \\
\hline
\end{tabular}

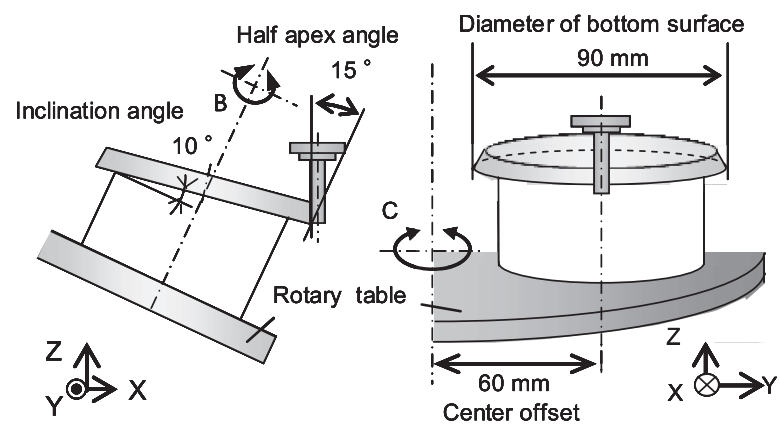

Fig.19 Work piece setting for cone frustum cutting motion

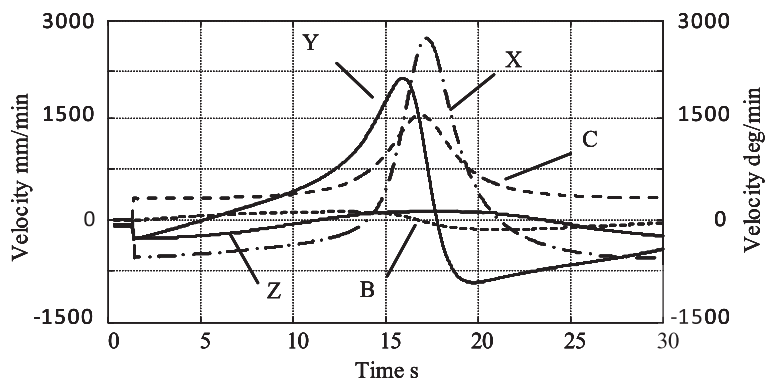

Fig.20 Velocity profile of each axis under cone frustum cutting motion

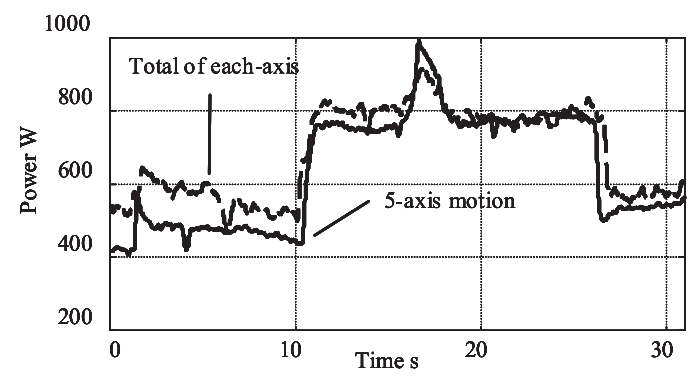

(a) Total power consumption

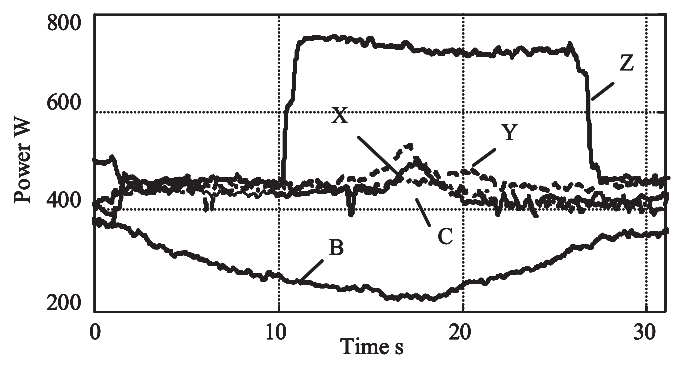

(b) Power consumption of each axis

Fig.21 Power consumption during cone-frustum cutting motion 
一方で，B 軸の消費電力は連続的に変化しているほか， Z 軸 上昇時には消費電力がステップ状に大きく増加しており， B 軸 および Z 軸はその動作範囲が小さいのにもかかわらず，消費電 力が大きく変化していることがわかる．このことから，重力の 影響を受ける B 軸および Z 軸はその動作範囲の大小によらず, 全体の消費電力に大きな影響を及ぼすといえる.

\section{6. 結 言}

本研究では, 立て形 5 軸マシニングセンタの送り駆動系にお ける消費電力を測定し，その大小に影響を及ぼす因子を調査し た. 以下に得られた結果を示す.

（1）送り駆動系の消費電力はモータの速度とトルクに依存す る.

（2）重力が作用する Z 軸および B 軸は，他の軸に比べて非常 に大きな電力を消費する，また，運動方向によって大き く違う.

（3） Z 軸停止中のモータトルクが摩擦特性に起因して直前の 運動方向に依存するために，停止中の消費電力も直前の 運動方向により変化する.

(4) 加減速時の消費電力は加減速パラメータの設定により変 化する. 加減速時定数は運動時間にも影響を及ぼし, 運 動に要するエネルギを最小にするパラメータが存在する。 位置ループゲインは運動時間に影響を及ぼすことなく, その運動に要寸る消費エネルギを削減可能である.

（5）同時多軸制御運動時の消費電力は各軸の消費電力の合計 となり．特に Z 軸および B 軸の消費電力の影響が支配的 である.

本研究の結果に基づいて, 各軸の運動やパラメータを変更す ることで送り駆動系の消費電力が削減可能となれば, 工作物の 設置方向や工具経路, 送り速度や加減速パラメータを適切に決 定するだけで消費電力の削減が実現できるようになり，工作機 械の消費電力削減に大きく貢献できると考えられる.

\section{謝辞}

本研究は，製造科学技術センター調査・研究助成，マザック 財団研究助成および昭和報公会研究助成により行われた研究の 一部であり，関係各位に深く感謝の意を表する．また，実験に 使用した機械はMTTRF から提供されたものであり，関係各位 に深く感謝の意を表する.

\section{参 考 文 献}

1) N. Diaz, S. Choi, M. Helu, Y. Chen, S. Jayanathan, Y. Yasui, D. Kong, S. Pavanaskar and D. Dornfeld: Machine Tool Design and Operation Strategies for green Manufacturing, Proceedings of 4th CIRPInternational Conference on High Performance Cutting, (2010).

2) C.herrman, S Thiede, S Kara, J.Hsselbach: Energy oriented simulation of manufacturing systems - consept and application, CIRP Annals, Manufacturing Technology, (2011) 45.

3) 成田浩久, 河村浩志, 則久孝志, 陳連怡, 藤本英雄, 長谷部孝男: 工作機械による加工の環境負荷予測システムの開発, 日本機械学 会 論文集(C 編), 71, 704, (2005)1392.

4) 下河辺学, 原雄太, 田中智久, 斉藤義夫: 工作機械の消費電力に関 する測定と評価, 2004 年度精密工学会秋季大会学術講演会講演論 文集, (2004) 68 .

5) 原雄太, 田中智久, 斎藤義夫: 工作機械の消費電力評価方法の構築, 2005 年度精密工学会春季大会学術講演会講演論文集, (2005) 459 .

6) M.Mori, M.Fujishima, Y.Inamasu, Y.Oda, A study on energy efficiency improvement for machine tools, CIRP Annals-Manufacturing Technology, (2011)145.

7) 佐藤隆太, 堤正臣: $\mathrm{AC}$ サーボモータと直動転がり案内を用いた送 り駆動系の数学モデル，精密工学会誌,71,(2005), 633

8) 堤正臣, 大友誠司, 岡崎裕一, 酒井浩二, 山崎和雄, 葛東方: 摩擦 を考慮した CNC 工作機械の送り駆動機構の数学モデル, 精密工学 会誌, 61, 10, (1995) 1458.

9) D.A.Haessig,Jr., B.Friedland : On the Modeling and Simulation of Friction, Joarnal of Dynamic Systems, Measument, and Control, 113 (1991) 354

10）深田茂生, 成瀬慎也, 松本貴広: ボールねじの微視的変位挙動に関 する研究(第 1 報)-淮静的特性に関する基礎実験-, 精密工学会誌, 66, (2000) 7.

11）大塚二郎, 青木一平, 石川智海: 転がり要素の非線形ば衩特性の研 究(第 1 報)：簡易測定法, 精密工学会誌 66, (2000) 944.

12）堺大陸, 松原厚: すべりの概念をいれたころがり案内の摩擦力の 解析, 第 9 回生産加工・工作機械部門講演会, (2012) 71.

13) N. Kato, R. Sato, M. Tsutumi: Analysis of Circular Trajectory Equivalent to Cone-frustum Milling in Five-axis Machining Centers using Motion Simulator, International Journal of Machine Tools \& Manufacture, 64 (2013) 1 . 